\title{
Distal Venous Arterialization and Reperfusion Injury: Focus on Oxidative Status
}

\author{
P. Djoric ${ }^{a} \quad J . Z^{2}$ Zeleskov-Djoric ${ }^{c}$ D.M. Stanisavljevic ${ }^{d} \quad$ Z.D. Markovic $^{b} \quad$ V. $^{\text {Zivkovic }}{ }^{f}$ \\ M. Vuletic ${ }^{f} \quad$ D. Djuric ${ }^{\text {e }}$ V. Jakovljevic ${ }^{f}$ \\ ${ }^{a}$ Clinic for Vascular and Endovascular Surgery and ${ }^{b}$ Center of Anesthesiology, Clinical Center of Serbia, ${ }^{C}$ Institute of \\ Criminological and Sociological Research, and IInstitute of Medical Statistics and Informatics, Faculty of Medicine \\ and 'Institute of Medical Physiology 'Richard Burian', School of Medicine, University of Belgrade, Belgrade, and \\ fDepartment of Physiology, Faculty of Medicine, University of Kragujevac, Kragujevac, Serbia
}

\section{Key Words}

Distal venous arterialization $\cdot$ Reperfusion injury $\cdot$ Oxidative status - Limb ischemia

\begin{abstract}
In patients with unreconstructable arterial occlusive disease distal venous arterialization (DVA) seems to be a promising option in the treatment. The goals of this prospective study were to assess clinical efficiency and possible impact of DVA on tissue damage by estimating oxidative status of patients with critical limb ischemia treated with this procedure. The subjects were 60 randomized patients: 30 were undergoing DVA and 30 were treated with antiaggregation therapy. During the mean follow-up period $(6.13 \pm 4.32$ months for DVA vs. $6.74 \pm 0.5$ months for antiaggregation therapy) survival $(p<0.01)$, limb salvage $(p<0.001)$, pain relief $(p<0.001)$ and wound healing $(p<0.001)$ rates were significantly different between the two groups of patients in favor of the DVA group. Ten minutes after declamping we observed a decreasing trend in the lactate level in the blood of the deep venous system $(p<0.001)$. Also, on postoperative day 7 digital systolic pressure and digital-brachial index were higher than before the operation $(p<0.001)$. In blood samples col-
\end{abstract}

lected immediately before and successively at 1, 3, 5 and 10 min postoperatively, prooxidative status (thiobarbituric acid reactive substances, $\mathrm{O}_{2}{ }^{-}, \mathrm{H}_{2} \mathrm{O}_{2}$ and nitric oxide) and antioxidative enzymes (superoxide dismutase, catalase and glutathione reductase) were determined spectrophotometrically. Using the nonparametric Friedman test, we noted statistically nonsignificant differences $(p>0.05)$ in values of both prooxidative parameters and enzymes of the antioxidative defense system, before and successively at 1, 3, 5 and $10 \mathrm{~min}$ after operation. These results indicate that there was no statistically significant reperfusion injury after revascularization, which could have been expected after this surgical procedure, thus confirming its validity in these patients.

Copyright $\odot 2012$ S. Karger AG, Basel

\section{Introduction}

Since the first experimental studies on animals dating back to the end of the 19th century up to the development of the 'more distal anastomosis' concept promoted by Lingua [1] in 1975 which represented a turning point in making the procedure successful, venous arterialization has been improving both technically and scientifically.

\section{KARGER}

Fax +4161306 1234

E-Mail karger@karger.ch

www.karger.com
(C) 2012 S. Karger AG, Basel

0014-312X/12/0484-0200\$38.00/0

Accessible online at:

www.karger.com/esr
Predrag Djoric, MD

Clinic for Vascular and Endovascular Surgery, Clinical Center of Serbia

8 Koste Todorovica st.

RS-11 000 Belgrade (Serbia)

Tel.+381 113065 176, E-Mail djoricpredrag@yahoo.com 
Despite confirmation of good early and late effects of revascularization by using distal venous arterialization (DVA) which do not only occur in specific cases, it is not a procedure which is regularly used by the modern-day vascular surgeon [2-5]. However, the development of DVA could move forward in the direction of researching the hemodynamics of the recipient microvascular bed, neovascularization and usage of the remodeled venous bed as an approach in adjuvant therapy, such as prostanoids and angiogenic growth factors. One of the stumbling blocks may be a risk of ischemic tissue damage after reperfusion.

On the other hand, an imbalance between oxidants and antioxidants, in favor of the oxidants potentially leading to damage, is termed 'oxidative stress' [6]. Oxidants are formed as a normal product of aerobic metabolism but can be produced at elevated rates under pathophysiological conditions. Antioxidant defense involves several strategies, both enzymatic and nonenzymatic ones. It is well known that during the ischemic period ATP is catabolized to yield hypoxanthine. During reperfusion, molecular oxygen is reintroduced into the tissue where it reacts with hypoxanthine and xanthine oxidase to produce a burst of superoxide anion and hydrogen peroxide. In the presence of iron, superoxide anion and hydrogen peroxide react via the Haber-Weiss reaction to form hydroxyl radicals. This highly reactive and cytotoxic radical then initiates a lipid peroxidation of cell membrane components, releasing various proinflammatory agents and consequently tissue damage [7].

Since there is a real possibility of reperfusion injury during revascularization, we would like to draw attention to the essential aim of this procedure - tissue reoxigenation. Regarding the fact that there are almost no articles covering this topic, we believe that this prospective randomized study might give us an answer as to whether DVA achieves useful oxygenation or worsens ischemia.

\section{Material and Methods}

From September 2009 to April 2011 at the Clinic for Vascular and Endovascular Surgery (Clinical Center of Serbia in Belgrade), 60 patients were treated for critical limb ischemia without the option for arterial reconstruction as a result of peripheral arterial occlusive disease with patent aortoiliac segment. From an unreconstructable cohort we chose 30 suitable patients for treatment with DVA. The remaining 30 patients were treated with the antiaggregation therapy (100 mg aspirin per day). Randomization was performed for sex, age, stage of disease, incidence of diabetes, hypertension and smoking.

Distal Venous Arterialization and

Reperfusion Injury
In all selected patients with critical limb ischemia monitoring consisted of measuring of ankle and digital systolic pressure, ultrasound examination of the venous system of the lower extremity and digital subtraction angiography were applied. Exclusion criteria for DVA were: (1) insufficient deep venous system and unsuitable great saphenous vein; (2) extensive infective and/or necrotic process up to the metatarsal level, and (3) poor prognosis of the patients. All operations were performed by a single surgeon.

\section{Surgical Technique}

The operations were performed under regional anesthesia with prophylactic antibiotics and intravenous heparin administration. The in situ technique was used in most of the cases. It consisted of the following steps: after dissection of the median marginal vein of the foot and great saphenous vein, we ligated all tributaries caudally up to the ankle and created lateroterminal anastomosis between the great saphenous vein and the in-flow artery. Valvulotomy was performed by introducing an expandable LeMaitre valvulotome through the more distal segment of the median marginal vein. Reverse vein bypass graft with the position of a distal anastomosis on the junction of the dorsal venous arch and the superficial vein of the thumb was used in 6 patients. In this way arterial blood flow was made possible in two directions, cranially, without valve resistance up to the ligated trunk of the great saphenous vein at the level of the medial mallelolus, and caudally through the dorsal venous arch after valvulotomy with a Fogarty catheter and a probe.

\section{Biochemical Assays}

For the determination of oxidative stress parameters blood samples of all 30 patients were collected (from the popliteal or femoral vein of the revascularized limb) immediately before and at $1,3,5$ and 10 min postoperatively. The prooxidative status was estimated by determination of the index of lipid peroxidation (measured as thiobarbituric acid reactive substances, TBARS), superoxide anion radical $\left(\mathrm{O}_{2}^{-}\right)$, hydrogen peroxide $\left(\mathrm{H}_{2} \mathrm{O}_{2}\right)$ and nitric oxide (NO) in plasma. The antioxidative defense system was estimated by determination of antioxidative enzymes in erythrocytes: superoxide dismutase (SOD), catalase (CAT) and glutathione reductase $(\mathrm{GSH})$. All parameters were determined spectrophotometrically (Analytic Jena Specord S 600).

\section{Determination of Index of Lipid Peroxidation (TBARS)}

Lipid peroxidation product malondialdehyde (MDA) concentration in plasma is determined by measuring TBARS using $1 \%$ thiobarbituric acid in $0.05 \mathrm{NaOH}$, incubated with plasma at $100^{\circ} \mathrm{C}$ for $15 \mathrm{~min}$ and read at $530 \mathrm{~nm}$ [8]. At high temperature and low $\mathrm{pH}$ value, MDA reacts with 2 -thiobarbituric acid via nucleophilic addition. The product of this reaction is a colored substance whose concentration of MDA correlates with the color intensity of this mixture. Distilled water was used as a blank probe. Thiobarbituric acid extract was obtained by combining $0.8 \mathrm{ml}$ plasma and $0.4 \mathrm{ml}$ trichloroacetic acid. After that samples were put on ice for $10 \mathrm{~min}$, and centrifuged for $15 \mathrm{~min}$ at 6,000 rpm.

\section{$\mathrm{O}_{2}^{-}$Determination}

Determination of $\mathrm{O}_{2}^{-}$plasma concentration was measured using a spectrophotometric method based on the reaction of $\mathrm{O}_{2}^{-}$ with nitro-blue tetrazolium in Tris buffer which formed nitroblue formazan [9]. Absorbance is registered at $550 \mathrm{~nm}$. 
Table 1. Demographic characteristics and risk factors of the patients

\begin{tabular}{lcll}
\hline Group & $\begin{array}{l}\text { Surgical pro- } \\
\text { cedure }\end{array}$ & Medication & $\mathrm{p}$ \\
\hline Sex & & & \\
$\quad$ Male & 21 & 17 & 0.211 \\
$\quad$ Female & 9 & 13 & \\
Age (mean \pm SD) & $65.37 \pm 10.87$ & $65.93 \pm 11.27$ & 0.844 \\
Stage of disease & & & \\
$\quad$ III & 9 & 14 & 0.144 \\
$\quad$ IV & 21 & 16 & \\
Hypertension & 11 & 15 & 0.217 \\
Diabetes & 21 & 17 & 0.211 \\
Smoking & 16 & 13 & 0.303 \\
Hyperlipidemia & 6 & 8 & 0.381 \\
Obesity & 6 & 5 & 0.500 \\
\hline
\end{tabular}

${ }^{1}$ Stage of disease by Fontaine.

Table 2. Comorbidity

\begin{tabular}{lrrl}
\hline Group & $\begin{array}{l}\text { Surgical } \\
\text { procedure }\end{array}$ & Medication & $\mathrm{p}$ \\
\hline Coronary artery disease & 12 & 12 & 0.604 \\
Carotid artery disease & 9 & 12 & 0.294 \\
Renal failure & 5 & 4 & 0.500 \\
COPD & 5 & 4 & 0.500 \\
\hline
\end{tabular}

COPD $=$ Chronic obstructive pulmonary disease.

\section{$\mathrm{H}_{2} \mathrm{O}_{2}$ Determination}

The protocol for measurement of $\mathrm{H}_{2} \mathrm{O}_{2}$ in plasma is based on oxidation of phenol red in the presence of horseradish peroxidase [10]. There were combined (1:20) 200- $\mu$ l samples with $800 \mu l$ phenol red solution and $10 \mu \mathrm{l}$ horseradish peroxidase (POD). The level of $\mathrm{H}_{2} \mathrm{O}_{2}$ was measured at $610 \mathrm{~nm}$.

\section{Determination of NO in Plasma}

NO decomposes rapidly to form stable metabolite nitrite $\left(\mathrm{NO}_{2}^{-}\right)$/nitrate products. The method for detection of the plasma nitrate and $\mathrm{NO}_{2}{ }^{-}$levels is based on the Griess reaction. $\mathrm{NO}_{2}{ }^{-}$was determined as an index of NO production with Griess reagent [11]. $0.1 \mathrm{ml} 3 \mathrm{~N}$ perchloride acid, $0.4 \mathrm{ml} 20 \mathrm{mmol} / \mathrm{l}$ ethylenediaminetetraacetic acid (EDTA) and $0.2 \mathrm{ml}$ plasma were put on ice for $15 \mathrm{~min}$, then centrifuged for $15 \mathrm{~min}$ at $6,000 \mathrm{rpm}$. After pouring off the supernatant, $220 \mu 1 \mathrm{~K}_{2} \mathrm{CO}_{3}$ was added. $\mathrm{NO}_{2}{ }^{-}$was measured at $550 \mathrm{~nm}$. Distilled water was used as a blank probe.

Determination of Antioxidant Enzymes

Isolated RBCs were washed 3 times with $3 \mathrm{vol}$ of ice-cold 0.9 $\mathrm{mmol} / \mathrm{l} \mathrm{NaCl}$. Hemolysates containing about $50 \mathrm{~g} \mathrm{Hb} / \mathrm{l}$ (prepared according to McCord and Fridovich [12]) were used for the determination of CAT activity. CAT activity was determined according to Beutler [13]. Lysates were diluted with distilled water (1:7 $\mathrm{v} / \mathrm{v})$ and treated with chloroform-ethanol $(0.6: 1 \mathrm{v} / \mathrm{v})$ to remove hemoglobin [14]. Then $50 \mu$ l CAT buffer, 100- $\mu$ l samples and $1 \mathrm{ml} 10 \mathrm{mmol} / 1 \mathrm{H}_{2} \mathrm{O}_{2}$ were added to the samples. Detection was performed at $360 \mathrm{~nm}$. Distilled water was used as a blank probe. SOD activity was determined by the epinephrine method of Misra and Fridovich [15]. $100 \mu$ l lysate and $1 \mathrm{ml}$ carbonate buffer were mixed, and then $100 \mu$ l of epinephrine were added. Detection was performed at $470 \mathrm{~nm}$.

\section{Determination of GSH}

Plasma level of reduced glutathione (GSH) was determined spectrophotometrically according to Beutler [13], and it is based on GSH oxidation via 5,5-dithio-bis-6,2-nitrobenzioc acid. GSH

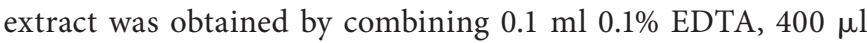
plasma and $750 \mu l$ precipitation solution (containing $1.67 \mathrm{~g}$ metaphosphoric acid, $0.2 \mathrm{~g}$ EDTA, $30 \mathrm{~g} \mathrm{NaCl}$ and filled with distilled water until $100 \mathrm{ml}$; the solution is stable for 3 weeks at $\left.+4^{\circ} \mathrm{C}\right)$. After mixing in the vortex machine and extraction on cold ice (15 $\mathrm{min})$, it was centrifuged on 4,000 rpm (10 min). Distilled water was used as a blank probe. Measuring was performed at $420 \mathrm{~nm}$.

\section{Statistical Analysis}

Analysis of the data was performed with the statistical evaluation, using Fisher's exact test, Student's t test, multivariate analysis of variance and Friedman's nonparametric test with the support and use of computer program SPSS version 12.0 for Windows.

\section{Results}

In the experimental and control group, the majority of the patients were male with an average age of 65 with gangrene or unhealed painful ulceration of the foot. They had significant accompanying comorbidity. In both groups, one to two thirds of the patients had at least one of the following risk factors such as diabetes, hypertension and smoking. Around $30-40 \%$ of the patients had carotid and/or coronary artery disease.

Primary features of the patients and comorbidity are shown in tables 1 and 2.

To investigate the short-term clinical outcome of DVA we observed survival, limb salvage, pain relief and wound healing. All of these parameters were improved after DVA compared with results in the patients treated conservatively (fig. 1).

One of the ways to assess success of the surgical revascularization of the extremity is measurement of the segmental arterial blood pressure. For the purposes of this study 7 days after DVA a digital systolic pressure on the foot and a digital-brachial index were measured by using the Doppler machine. The use of the Student $t$ test showed that there were no statistically significant differences in 


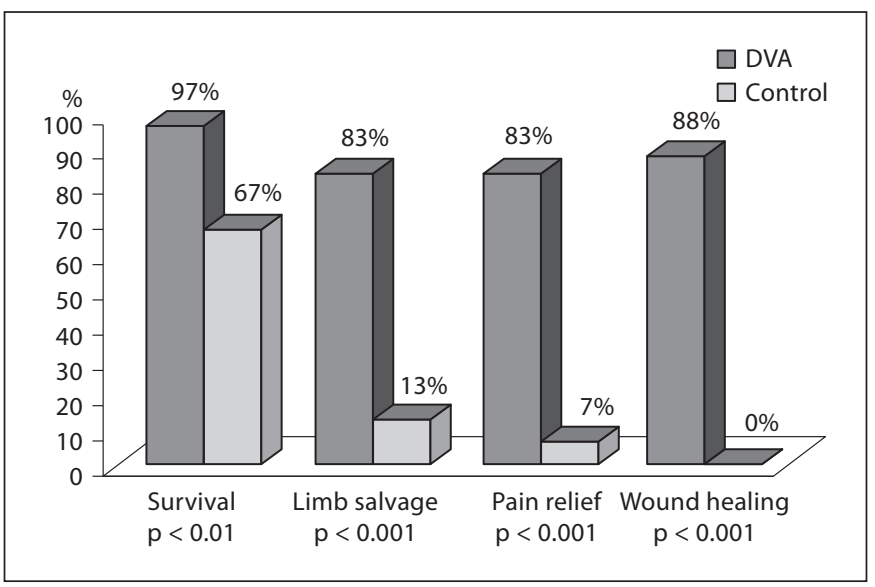

Fig. 1. Clinical outcomes after DVA and antiaggregation therapy.

Table 3. Preoperative digital systolic pressure (DSP) and digitalbrachial index (DBI)

\begin{tabular}{llllll}
\hline Pressure & Group & $\mathrm{n}$ & Mean & SD & $\mathrm{p}$ \\
\hline DSP & DVA & 30 & 30.67 & 7.512 & 0.676 \\
& Control & 30 & 31.40 & 5.917 & \\
\hline DBI & DVA & 30 & 0.233 & 0.060 & 0.582 \\
& Control & 30 & 0.225 & 0.051 & \\
\hline
\end{tabular}

Average value of the pressure $(\mathrm{mm} \mathrm{Hg})$ and index.

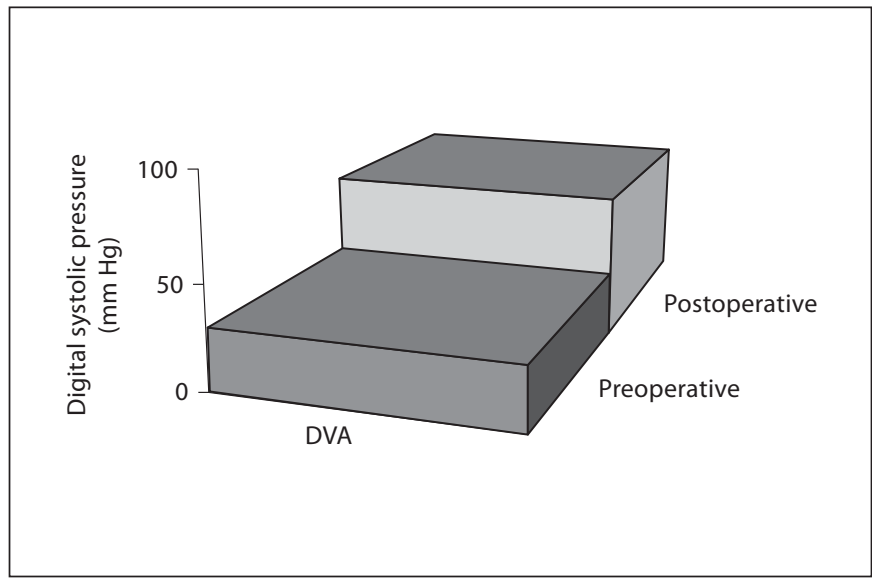

Fig. 2. Hemodynamic changes after DVA.

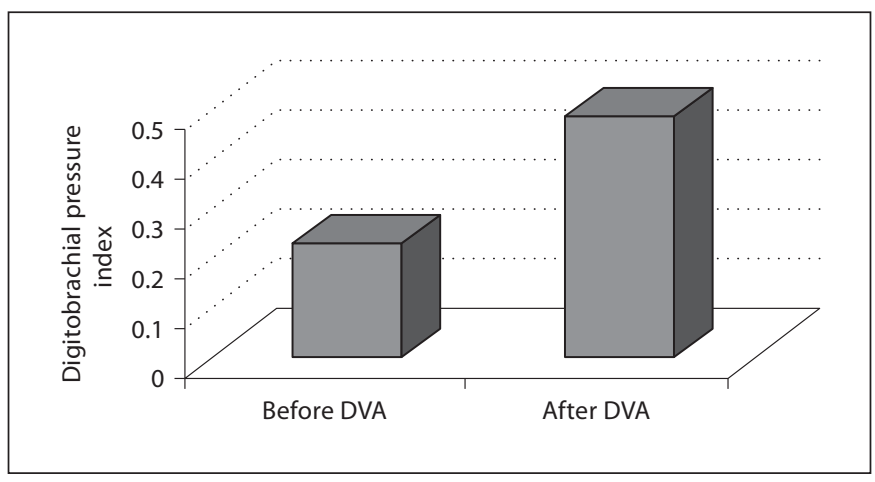

Fig. 3. Digital-brachial index improvement after DVA.

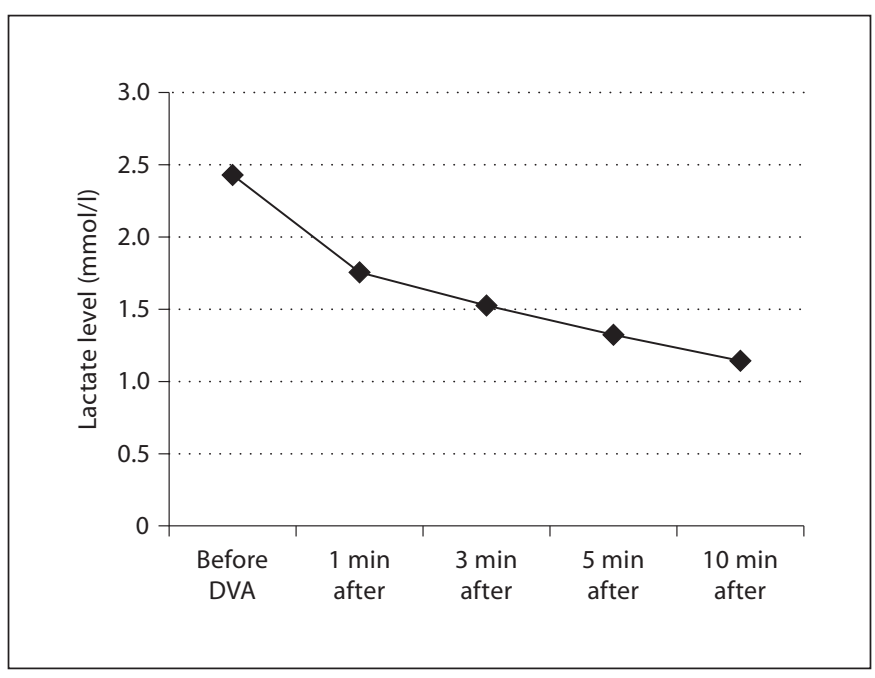

Fig. 4. Decreasing trend of the lactate level after DVA. 
Table 4. Values of prooxidant parameters

\begin{tabular}{|c|c|c|c|c|c|c|c|c|c|c|}
\hline & \multicolumn{2}{|l|}{ Before DVA } & \multicolumn{2}{|l|}{$1 \mathrm{~min}$ after } & \multicolumn{2}{|l|}{3 min after } & \multicolumn{2}{|l|}{5 min after } & \multicolumn{2}{|l|}{10 min after } \\
\hline & mean $\pm \mathrm{SD}$ & median & mean $\pm S D$ & median & mean $\pm S D$ & median & mean $\pm S D$ & median & mean $\pm S D$ & median \\
\hline TBARS & $1.86 \pm 1.91$ & 1.37 & $3.18 \pm 2.65$ & 1.62 & $4.09 \pm 2.82$ & 3.59 & $3.17 \pm 2.76$ & 2.65 & $2.97 \pm 1.89$ & 3.90 \\
\hline $\mathrm{H}_{2} \mathrm{O}_{2}$ & $3.26 \pm 1.00$ & 2.96 & $3.15 \pm 0.75$ & 2.78 & $4.39 \pm 3.60$ & 3.64 & $3.13 \pm 0.58$ & 3.03 & $3.68 \pm 1.26$ & 3.40 \\
\hline $\mathrm{O}_{2}^{-}$ & $7.92 \pm 4.95$ & 7.02 & $12.13 \pm 5.67$ & 13.69 & $17.44 \pm 15.19$ & 14.95 & $19.12 \pm 12.0$ & 16.73 & $16.6 \pm 14.9$ & 11.15 \\
\hline $\mathrm{NO}$ & $10.44 \pm 4.92$ & 8.45 & $13.41 \pm 3.48$ & 12.96 & $15.33 \pm 8.04$ & 15.94 & $10.26 \pm 4.18$ & 9.17 & $9.82 \pm 6.29$ & 9.87 \\
\hline
\end{tabular}

Mean \pm SD represents average value \pm standard deviation. Reference values of oxidative stress parameters: TBARS $=1 \mu$ mol/l; $\mathrm{H}_{2} \mathrm{O}_{2}=10-15 \mathrm{nmol} / \mathrm{l} ; \mathrm{O}_{2}^{-}=10-15 \mathrm{nmol} / \mathrm{l} ; \mathrm{NO}=15-20 \mathrm{nmol} / \mathrm{l}$.

Table 5. Values of antioxidant enzymes

\begin{tabular}{|c|c|c|c|c|c|c|c|c|c|c|}
\hline & \multicolumn{2}{|l|}{ Before DVA } & \multicolumn{2}{|l|}{$1 \mathrm{~min}$ after } & \multicolumn{2}{|l|}{3 min after } & \multicolumn{2}{|l|}{5 min after } & \multicolumn{2}{|l|}{10 min after } \\
\hline & mean $\pm \mathrm{SD}$ & median & median $\pm \mathrm{SD}$ & median & median $\pm \mathrm{SD}$ & median & median $\pm \mathrm{SD}$ & median & median $\pm \mathrm{SD}$ & median \\
\hline CAT & $48.7 \pm 28,8$ & 32.1 & $53.8 \pm 30.8$ & 43.8 & $60.5 \pm 56.2$ & 43.8 & $71.6 \pm 97.4$ & 39.6 & $51.9 \pm 43.6$ & 40.7 \\
\hline SOD & $1,668 \pm 1,236$ & 1,839 & $2,187 \pm 2,515$ & 1,465 & $2,420 \pm 2,661$ & 2,116 & $2,689 \pm 2,155$ & 2,983 & $2,096 \pm 1,659$ & 1,851 \\
\hline GSH & $43.48 \pm 30.32$ & 42.51 & $48.16 \pm 28.27$ & 54.13 & $34.04 \pm 30.17$ & 27.81 & $42.36 \pm 27.6$ & 43.38 & $38.95 \pm 28.0$ & 42.5 \\
\hline
\end{tabular}

Mean \pm SD represents average value \pm standard deviation. Reference values of antioxidant enzymes: $\mathrm{CAT}=2-2.5 \mathrm{U} / \mathrm{g} \mathrm{Hb} \times 10^{3}$; $\mathrm{SOD}=1,500-2,000 \mathrm{U} / \mathrm{g} \mathrm{Hb} \times 10^{3} ; \mathrm{GSH}=20-25 \mu \mathrm{mol} / \mathrm{ml}$.

Table 6. Complications of DVA

\begin{tabular}{lc}
\hline Complications & $\mathrm{n}$ \\
\hline General & \\
$\quad$ Pneumonia & 1 \\
$\quad$ Cardiac decompensation & 2 \\
Surgical & 1 \\
$\quad$ Infection & 2 \\
$\quad$ Bleeding & 6 \\
Graft thrombosis & 3 \\
$\quad$ Leg swelling & 15 \\
\hline All
\end{tabular}
bosis.

One patient had simultaneous bleeding and early graft throm-

Tables 4 and 5 show values registered at the measurement of the oxidative stress in 10 patients immediately before DVA and successively at 1, 3, 5 and 10 min postoperatively. Table 4 shows levels of estimated prooxidant parameters before DVA and at 1, 3, 5 and 10 min postoperatively. Using the nonparametric Friedman test ( $p>$ $0.05)$, it was observed that there was no significant differ- ence in any prooxidant molecule at all times of measurement. Table 5 shows data of the enzymes of the antioxidative defense system before DVA and at 1, 3, 5 and $10 \mathrm{~min}$ after this procedure. Again, using the nonparametric Friedman test $(p>0.05)$, it was noted that there was no significant difference in any antioxidant enzymes between all times of measurement.

Surgical complications in a narrow sense started developing in $8(26.6 \%)$ patients (table 6). These complications meant infection of operative incision, graft thrombosis and bleeding. The early postoperative process was complicated with the development of pneumonia in $1 \mathrm{pa}-$ tient, with a cardiac decompensation in 2 patients and with the fatal outcome in 1 patient.

\section{Discussion}

Revascularization of critically ischemic limbs unsuitable for standard reconstructive surgical procedure is a surgical dilemma with a long prehistory. At the beginning of the 20th century, the only method of treatment of patients with gangrene of the extremities caused by atherosclerosis was high amputation. In 1896, the first clini- 
cal report about arteriovenous reversal was published [16]. In 1912, Halstead and Vaughan [17] reviewed 42 cases and revealed only 1 patient with apparent perioperative pulsation of the foot veins who survived for 4 months without extension of the gangrene. The concept of reverse flow has been revised in 1951, when Szilagyi et al. [18] reported nine failures in 9 patients. They created a fistula between the common femoral artery and superficial femoral vein, reaffirming the view that the reverse flow is possible without destruction of venous valves. The reason for the failure in all patients can be explained with the small sample; they agree with Halstead and Vaughan that anoxia and the presence of fistulas are important for the formation of collateral flow. In 1975, Lengua [1] introduced the concept of a more distal anastomosis and achieved success in 3 of 8 patients. Originally, he did not perform valvulotomy preserving the dorsal venous arch and attributed success to the valves commonly absent from the superficial foot veins. Almost 20 years later, the same author published a series of 26 patients using terminolateral anastomosis between the great saphenous vein and the medial marginal vein, with mechanical valve destruction [19]. But this time after an average follow-up period of 1 year and 3 months, an average graft flow of $73 \%$ was reached. A similar success in $50 \%$ of the 6 patients was achieved by Sheil [20], by applying the technique of distal arterialization with destruction of the dorsal venous valve portion. After 18 months of follow-up, $20 \%$ of the fistula was left with a surprising functional limb preservation rate of $50 \%$, indicating the viability of collateral circulation after graft occlusion. The best results of critically ischemic limb treatment using DVA were achieved by Pokrovsky et al. [3] in the largest published study so far. Metallic olives were used to break down the valves without direct visualization. They reported 85 cases with $80 \%$ limb salvage. In recent years the number of papers with optimistic results has been increasing [21-23]. In everyday surgical practice, most vascular surgeons in patients without the option for femorodistal reconstructions consider the application of drugs (antiplatelet agents or prostanoids), spinal cord stimulation, and hyperbaric oxigenotherapy, but these are still limited and with modest results [24, 25].

What certainly justifies the performance of DVA as a limb salvage procedure are the acceptable morbidity and mortality rates which follow this procedure. In this study the mortality rate after DVA was 3.3\%, while in conservatively treated patients it reaches $33.3 \%$ after an average 6-month follow-up period. According to our experience in a smaller group of patients, the outcome was signifi-

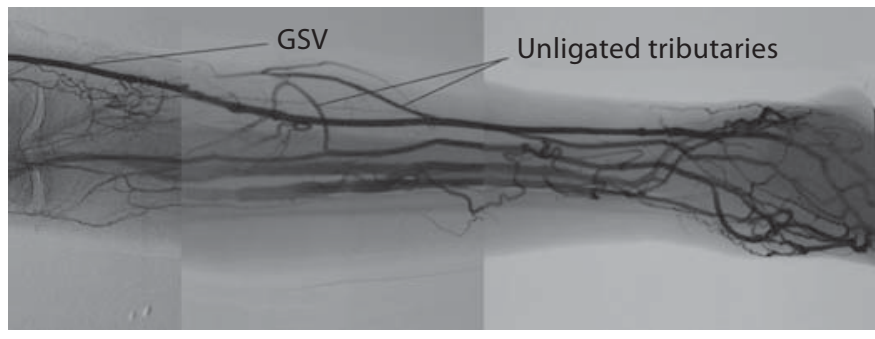

Fig. 5. Unligated tributaries of the great saphenous vein (GSV) in situ.

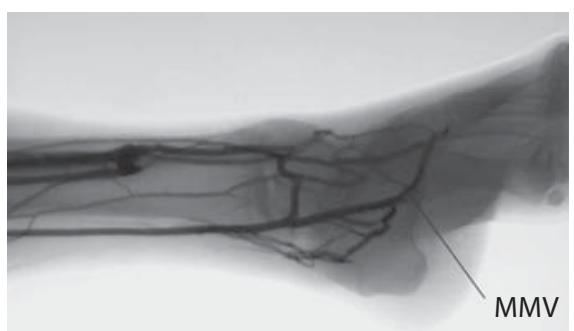

Fig. 6. Incompetent dorsal venous arch of the foot with patent median marginal vein (MMV) and occlusion of the digital veins.

cantly improved [5]. Despite the similar comorbidity rate in both groups, only 1 patient treated with DVA died of cardiac decompensation. The patient had patent graft and wound healing on the foot. Most of the patients in the control group, 8 out of 10 , died of the septic complications of the foot gangrene.

Most of the patients in the DVA group with a patent graft, 22 out of 25 , achieved pain relief at rest and improved walking capacity, therefore improving the functional status of the extremities. In 3 patients with a patent graft the gangrene process was not stopped, which required an urgent high amputation of the extremities. In 2 patients with control angiography a technical error was detected, which is illustrated in figures 5 and 6 . After ligature of the overlooked tributaries the clinical status in the first patient did not get better, and in the second case an additional procedure to improve run-off was not possible. Finally, high leg amputation was necessary.

An ischemic ulcer healed successfully in 21 of 24 patients, all of whom had a patent graft. One of the indicators of the successful reverse revascularization of the leg was the increase in the digital systolic pressure from an average of $30.67 \pm 7.5 \mathrm{~mm} \mathrm{Hg}$ before the operation to 
$68.4 \pm 16.2 \mathrm{~mm} \mathrm{Hg} 7$ days postoperatively ( $\mathrm{p}<0.001$ ). Also, in the same period of time the systolic digital-brachial pressure index increased from $0.233 \pm 0.60$ before the operation to $0.497 \pm 0.147$ postoperatively $(\mathrm{p}<0.001)$.

The surplus of the ischemic region lactate which is the result of the anaerobic metabolism is being gradually eliminated within the first $10 \mathrm{~min}$ after revascularization. There are two ways of eliminating the surplus of the lactate from the ischemic region. One is the conversion of the lactate into glucose, by the process of the gluconeogenesis in the liver, known as the Cori cycle. Nevertheless, this can hardly explain the rapid fall in the lactate level in venous blood of the revascularized extremity. A more rational way of explaining this rapid fall of the lactate is the oxygenation into pyruvates, which normally occurs during exertion in well-oxygenated muscle cells. Pyruvate created in this way can easily join the well-known Krebs cycle for producing energy in the form of ATP. Therefore, we would argue that DVA improves not only skin circulation - the most endangered tissue in critical limb ischemia - but also circulation of the muscles of the foot.

As we know, revascularization of the ischemic tissues may be followed by microvascular dysfunction, which leads to local and remote cellular and organ failure. Pathophysiology of ischemia-reperfusion injury concerns impaired endothelium-dependent, NO-mediated relaxation of smooth muscle to all receptor-dependent vasodilators in arterioles; enhanced capillary fluid filtration and the plugging of capillaries by stiffer, activated leukocytes with capillary malperfusion; leukocyte-endothelial cell adhesion, transendothelial leukocyte migration, platelet-leukocyte aggregation, albumin extravasation and enhanced oxidant production in postcapillary venules, and $\mathrm{NO}$-superoxide imbalance in endothelial cells tipped in favor of superoxide [26-29]. Unfortunately, this scenario is not predictable but might be modified in the process termed acute or classical preconditioning and delayed preconditioning or ischemic tolerance $[30,31]$.

On the other hand, it is interesting that, considering pathophysiological mechanism of reperfusion injury, there are almost no data about the effect of DVA on oxidative status and cell damage. Analyzing the dynamics of oxidative stress of parameters (TBARS, $\mathrm{O}_{2}^{-}, \mathrm{H}_{2} \mathrm{O}_{2}$ and $\mathrm{NO}_{2}{ }^{-}$) as well as the reply of the antioxidant system (SOD, CAT and GSH) after surgical revascularization of the foot, we can observe that DVA did not cause significant variations of all estimated parameters. Intervention did not improve antioxidant defense (which can be hardly expected because the tissue is not healthy), but more importantly, it did not increase oxidative stress. This result could be an acute response of local circulation, suggesting that there was no significant reperfusion injury, which can be expected after this kind of surgical procedure. At this stage of research, we still cannot determine why this occurred. One of the answers could be the development of 'controlled reperfusion', which in this case (retrograde perfusion through superficial venous system) provides adequate oxygenation with minimum damaging of the cells. However, it is certain that these pathophysiological events require further research. In the latest medical database search (PubMed) only few papers covering this problem could be found. It has been shown that the prostacyclin analogue $\left(\mathrm{PGI}_{2}\right)$ iloprost decreases the system level of oxidative stress parameters in patients with peripheral vascular disease [32]. Also, preoperative administration of L-alanyl-glutamine $(250 \mathrm{ml})$ caused protection of the local tissue after surgical revascularization in patients with peripheral vascular disease versus those without this therapy [33].

\section{Conclusion}

When comparing our results with other studies, we can conclude that, in our case, DVA did not induce reperfusion injury but has achieved the therapeutically goaladequate reoxygenation of ischemic tissue.

\section{Acknowledgment}

This work was supported by the grant No. 175043 from the Ministry of Science and Technical Development of the Republic of Serbia.

References $\quad 1 \begin{aligned} & \text { Lengua F: Technique d'artérialisation du ré- } \\ & \text { seau veineux du pied. Nouv Presse Med 1975; } \\ & \\ & 4: 1039-1042 .\end{aligned}$

Djoric et al. 
5 Djoric P: Early individual experience with distal venous arterialization as a lower limb salvage procedure. Am Surg 2011;77:726730.

$\checkmark 6$ Sies H: Oxidative stress: oxidants and antioxidants. Exp Physiol 1997;82:291-295.

7 Granger DN: Role of xanthine oxidase and granulocytes in ischemia-reperfusion injury. Am J Physiol 1988;255:H1269-H1275.

8 Ohkawa H, Ohishi N, Yagi K: Assay for lipid peroxides in animal tissues by thiobarbituric acid reaction. Anal Biochem 1979;95:351358.

9 Auclair C, Voisin E: Nitroblue tetrazolium reduction; in Greenvvald RA (ed): Handbook of Methods for Oxygen Radical Research. CRC Press Une., Boca Raton, 1985; pp 123-132.

10 Pick E, Keisari Y: A simple colorimetric method for the measurment of hydrogen peroxide produced by cells in culture. J Immunol Methods 1980;38:161-170.

11 Green LC, Wagner DA, Glogowski J, Skipper Pl, Wishnok JS, Tannenbaum SR: Analysis of nitrate, nitrite and $[15 \mathrm{~N}]$ nitrate in biological fluids. Anal Biochem 1982;126:131-138.

12 McCord JM, Fridovich I: The utility of superoxide dismutase in studying free radical reactions. I. Radicals generated by the interaction of sulfite, dimethyl sulfoxide, and oxygen. J Biol Chem 1969;244(22):6056-6063.

13 Beutler E: Catalase; in Beutler E (ed): Red Cell Metabolism, a Manual of Biochemical Methods. Grune and Stratton, New York 1982; pp 105-105.

14 Tsuchihashi M: Zur Kenntnis der Blutkatalase. Biochem Z 1923; 140:65-72.

15 Misra HP, Fridovich I: The role of superoxide-anion in the autooxidation of epinephrine and a simple assay for superoxide dismutase. J Biol Chem 1972;247:3170-3175.
16 Francois-Franck M: Note à propos de la communication de M Raimond Petit sur la susture artério-veneuse. Compt Rend Hebd Soc Biol 1896;48:150.

17 Halstead AE, Vaughan RT: Arteriovenous anastomosis in the treatment of gangrene of the extremities. Surg Gynecol Obstet 1912; $14: 1$.

18 Szilagyi DE, Jay GE, Munnel ED: Femoral arteriovenous anastomosis in the treatment of occlusive arterial disease. AMA Arch Surg 1951;63:435.

19 Lengua F, Nuss JM, Buffet JM, Lechner R: Etude comparative de deux modalités d'artérialisation des veines du pied en ischémie critique. J Chir (Paris) 1993;130:12.

20 Sheil AGR: Treatment of critical ischaemia of the lower limb by venous arterialisation: an interim report. Br J Surg 1977;64:197-199.

21 Engelke C, Morgan RA, Quarmby JW, Taylor RS, Belli AM: Distal venous arterialization for lower limb salvage: angiographic appearances and interventional procedures. Radiographics 2001;21:1239-1248.

22 Rowe VL, Hood DB, Lipham J, Terramani T, Torres G, Katz S, et al: Initial experience with dorsal venous arch arterialization for limb salvage. Ann Vasc Surg 2002;16:187-192.

23 Ozbek C, Kestelli M, Emrecan B, Ozsoyler I, Bayatli K, Yasa $\mathrm{H}$, et al: A novel approach: ascending venous arterialization for atherosclerosis obliterans. Eur J Vasc Endovasc Surg 2005;29:47-51

24 Gersbach PA, Argitis V, Gardaz J-P, et al: Late outcome of spinal cord stimulation for unreconstructable and limb-threatening lower limb ischemia. Eur J Vasc Endovasc Surg 2007;33:717-724

25 Norgren L, Alwmark A, Angqvist KA, et al: A stable prostacyclin analogue (iloprost) in the treatment of ischemic ulcers of the lower limb: a Scandinavian-Polish placebo controlled randomized multicenter study. Eur J Vasc Surg 1990;4:463-467.
26 Banda MA, Lefer DJ, Granger DN: Postischemic endothelium-dependent vascular reactivity is preserved in adhesion molecule-deficient mice. Am J Physiol 1997;273:H2721H2725.

27 Skalak R, Skalak TC: Flow behavior of leukocytes in small tubes; in Granger DN, SchmidSchonbein GW (eds): Physiology and Pathophysiology of Leukocyte Adhesion. New York, Oxford University Press, 1995, pp 97115.

28 Granger DN: Ischemia-reperfusion: mechanisms of microvascular dysfunction and the influence of risk factors for cardiovascular disease. Microcirculation 1999;6:167-178.

29 Granger DN: Physiology and pathophysiology of the microcirculation. Prog Cardiovasc Med 1998;3:123-140.

30 Jerome S, Akimitsu T, Gute D, Korthuis R: Ischemic preconditioning attenuates capillary no-reflow induced by ischemia and reperfusion. Am J Physiol 1995;268:20632067.

31 Korthuis RJ, Gute DC, Cepinska G, Kvietys PR: Cellular mechanisms of acute versus delayed preconditioning. Pathophysiology 1998;5:35-48.

-32 Lessiani G, Vazzana N, Cuccurullo C, Di Michele D, Laurora G, Sgrò G, Di Ruscio P, Simeone E, Di Iorio P, Lattanzio S, Liani R, Ferrante E, Davì G: Inflammation, oxidative stress and platelet activation in aspirin-treated critical limb ischaemia: beneficial effects of iloprost. Thromb Haemost 2011;105:321328 .

-33 Alves WF, Aguiar EE, Guimarães SB, da Silva Filho AR, Pinheiro PM, Soares Gdos S, de Vasconcelos PR: L-Alanyl-glutamine preoperative infusion in patients with critical limb ischemia subjected to distal revascularization reduces tissue damage and protects from oxidative stress. Ann Vasc Surg 2010; 24:461-467. 